Steroids. 2009 March ; 74(3): 296-305. doi:10.1016/j.steroids.2008.10.003.

\title{
Androgens and Bone
}

Bart L. Clarke, M.D. and

Mayo Clinic W18-A, $2001^{\text {st }}$ Street SW, Rochester, Minnesota, USA 55905, Phone: 507-266-4322, Fax: 507-284-5745

Sundeep Khosla, M.D.

Mayo Clinic Endocrine Research Unit, Guggenheim 7, $2001^{\text {st }}$ Street SW, Rochester, Minnesota, USA 55905, Phone: 507-285-6663, Fax: 507-284-9111

\section{Abstract}

Testosterone is the major gonadal sex steroid produced by the testes in men. Testosterone is also produced in smaller amounts by the ovaries in women. The adrenal glands produce the weaker androgens dehydroepiandrosterone, dehydroepiandrosterone sulfate, and androstenedione. These androgens collectively affect skeletal homeostasis throughout life in both men and women, particularly at puberty and during adult life. Because testosterone can be metabolized to estradiol by the aromatase enzyme, there has been controversy as to which gonadal sex steroid has the greater skeletal effect. The current evidence suggests that estradiol plays a greater role in maintenance of skeletal health than testosterone, but that androgens also have direct beneficial effects on bone. Supraphysiological levels of testosterone likely have similar effects on bone as lower levels via direct interaction with androgen receptors, as well as effects mediated by estrogen receptors after aromatization to estradiol. Whether high doses of synthetic, non-aromatizable androgens may, in fact, be detrimental to bone due to suppression of endogenous testosterone (and estrogen) levels is a potential concern that warrants further study.

\section{Introduction}

Androgens are critical for differentiation of male gonadal structures prior to birth, for sexual maturation during puberty, and for maintenance of male secondary sexual characteristics and genital function, including spermatogenesis, in adulthood. Because men have larger skeletons and greater muscle mass than women, it is assumed that this sexual dimorphism is due, at least in part, to increased androgen levels in men. The specific role of androgens in muscle, cardiovascular tissue, the central nervous system, and the immune system is being actively investigated, while the role played by androgens in bone is increasingly well understood due to many animal and human studies over the last three decades [1].

Albright and Reifenstein recognized that androgens help prevent bone loss and osteoporosis in aging men, and that androgens play a role in building the skeleton in young adults [2]. Since that time, because osteoporosis affects more women than men, most research studies on gonadal sex steroids and bone have focused on the effect of estrogens on bone. Testosterone is metabolized via the cytochrome $\mathrm{P} 450$ aromatase enzyme complex into 17ß-estradiol, and increasing evidence indicates that at least part of the effect of androgens on bone is mediated by their aromatization to estrogens [3,4]. Epiphyseal closure in late puberty is dependent predominantly on estrogens in both men and women [5], and estrogens appear to play a greater

Address all correspondence and requests for reprints to: Bart L. Clarke, M.D., Mayo Clinic W18-A, $2001^{\text {st }}$ Street SW, Rochester, Minnesota, USA 55905, Phone: 507-266-4322, Fax: 507-284-5745.

Institution From Which Work Originated: Mayo Clinic, $2001^{\text {st }}$ Street SW, Rochester, Minnesota, USA 55905 
role than testosterone in preventing bone loss in elderly men [6,7]. Because of these observations, it has been questioned whether androgens play a significant direct role in skeletal physiology, although androgen receptors are present on bone cells, and androgen receptormediated actions on bone have been known for several years [8,9].

This review will summarize the currently recognized actions of androgens on the skeleton during development and aging, and review the available evidence that androgens affect skeletal physiology when used in physiological doses. Given the absence of data on effects of supraphysiological doses of androgens used to enhance athletic performance on bone, one can only speculate on whether these higher doses will have similar effects on bone or other, untoward actions.

\section{Androgen Receptors in Bone Cells}

Androgen receptors are expressed in cultured epiphyseal chondrocytes [10] and growth plate cartilage cells [11], as detected by immunohistochemistry, binding studies, and in situ hybridization. These receptors are expressed in all layers of the human growth plate at different ages [12], but only in the proliferative and early hypertrophic chondrocytes in sexually mature rats, and only in prehypertrophic chondrocytes in older rats [13]. No differences have been detected in androgen receptor expression in growth plate chondrocytes from human males or females $[10,12]$, whereas male rats have increased androgen receptor expression in the growth plate and metaphyseal bone during sexual maturation compared to female rats [13]. In light of these findings, it is likely that androgens directly influence longitudinal bone growth during early puberty and epiphyseal growth plate closure in later puberty. Expression of ER $\alpha$ and $E R \beta$ in the human growth plate makes it possible that androgens also indirectly affect pubertal growth or epiphyseal closure via aromatization to estrogen [14,15].

Androgen receptors and ER $\alpha$ and ER $\beta$ are also reported in osteoblasts using more sensitive detection techniques. Early studies failed to detect these receptors in osteoblasts. Androgen receptors were first detected in cultured human fetal osteoblasts using a nuclear binding assay in 1989 [16]. Subsequent studies have detected androgen receptor mRNA and protein in both osteoblasts and osteocytes [11,17]. The number of binding sites per cell is reported to vary widely from 70 to 14,000 [18], depending on the assay used. This wide variation in binding site number per cell is within the range seen in other androgen target tissues.

Human osteoblastic cells from cortical bone express more androgen receptor mRNA and have greater androgen binding than cells from trabecular bone, but osteoblasts from males and females express similar number of androgen receptors [19]. Most, but not all, studies show that androgens upregulate the expression of androgen receptors in osteoblasts $[17,19,20]$. ER $\alpha$ and ER $\beta$ are also expressed in osteoblasts and osteocytes. There is no current consensus regarding the relative expression of androgen receptors and ER $\alpha$ and ER $\beta$ during osteoblast or osteocyte differentiation, or their localization within the skeleton.

Androgen receptors have been detected in avian [21] and mouse osteoclasts [22] in vitro, and in rat osteoclasts in vivo [23], but not yet in human osteoclasts in vivo [11]. Because of the decreased evidence for androgen receptors in osteoclasts to date, it is assumed that androgens exert most of their effects on osteoclastogenesis and bone resorption via osteoblasts or osteocytes. However, androgens have been shown to directly promote osteoclast apoptosis in several in vitro studies.

Androgen receptors have been found to be expressed by osteoblast precursor bone marrow stromal cells [24], as well as on megakaryocytes and endothelial cells within the bone marrow [25]. 


\section{Synthetic Androgen Actions on Bone}

There is little published information on the action or metabolism of synthetic androgens in bone cells, or the mechanism of action of synthetic androgens in bone. Synthetic androgens presumably exert receptor-mediated and nongenomic actions similar to gonadal androgens, although no studies have reported such an effect. Presumably synthetic androgens act via classical androgen receptors in bone similar to gonadal and adrenal androgens.

\section{Androgen Effects on Skeletal Cells}

Androgens likely stimulate longitudinal bone growth by their direct effects on growth plate chondrocytes. Under strict culture conditions, androgens regulate both proliferation and differentiation of cultured epiphyseal chondrocytes [10]. Testosterone injected directly into the rat growth plate increases the width of the growth plate [26]. Part of the effect of androgens on longitudinal bone growth may be mediated by indirect effects on pituitary function, because androgens modulate the kinetics of growth hormone secretion during puberty [27].

Both testosterone and $5 \alpha$-dihydrotestosterone stimulate proliferation of cultured osteoblast precursors in different species [28-30], but their effects on osteoblast differentiation are less clear. Studies have shown stimulatory or inhibitory effects, as well as no effect, on osteoblast expression of alkaline phosphatase, type 1 collagen, osteocalcin, and mineralization of extracellular bone matrix, but the weight of evidence suggests that androgens generally stimulate osteoblast differentiation [28,30,31]. Androgens have also been shown to decrease osteoblast and osteocyte apoptosis.

Androgen effects on bone may also be indirectly mediated by regulation of cytokines and growth factors expressed locally in bone. Androgens upregulate Transforming Growth Factor (TGF)- $\beta$ and Insulin-like Growth Factors (IGFs), which stimulate bone formation [29,30], and downregulate Interleukin (IL)-6, which stimulates osteoclastogenesis [32]. Androgens inhibit parathyroid hormone (PTH)- or IL-1-induced prostaglandin (PG)E2 production [33], and PTHinduced cAMP production [34]. Androgens stimulate IL-1 $\beta$ production [35] and enhance the mitogenic effect of fibroblast growth factor (FGF) in cultured osteoblasts [29].

Dihydrotestosterone has been shown to reduce osteoprotegerin (OPG) levels, which could potentially stimulate osteoclast activity [36].

Osteoclasts derived from the bone marrow colony forming unit-granulocyte macrophage (CFU-GM) hematopoietic cell lineage undergo proliferation after orchiectomy, presumably mainly due to androgen deficiency. Osteoclast differentiation requires contact with stromal cells of the osteoblastic lineage in the bone marrow microenvironment, and stimulation by receptor activator of nuclear factor $\mathrm{\kappa B}$ ligand (RANKL) expressed and secreted by osteoblastic cells, which binds to RANK on osteoclasts [37]. RANKL effects on osteoclasts are tightly regulated via secretion of osteoprotegerin (OPG), a decoy receptor for RANKL, by osteoblast precursors.

Androgens appear to exert their bone protective effects, in part, indirectly through osteoblastic cells. Orchiectomy normally results in increased osteoblast precursor cells that indirectly stimulate osteoclast proliferation and activation via RANKL expression, leading to bone loss. Dihydrotestosterone binds directly to androgen receptors on osteoclasts and blocks bone resorption by human, mouse, and avian osteoclasts in vitro [11]. In cell culture, androgens have been shown to directly regulate RANKL-induced osteoclast formation [38], osteoclast survival, RANK expression by preosteoclasts, and mature osteoclast function independent of bone marrow stromal osteoblast precursors. In conclusion, androgens appear to be capable of regulating osteoclastogenesis both indirectly and directly. 


\section{Effects of Androgens on the Human Skeleton}

\section{Castration}

Surgical or chemical orchiectomy, induced by GnRH agonist therapy, result in rapidly decreased gonadal sex steroid levels in men [39]. This decrease in gonadal steroids is associated with rapid bone loss, similar to that seen in women after surgical oophorectomy or early menopause, as well as decreased lean body mass and muscle mass. Rapid bone loss is particularly pronounced at trabecular sites in the skeleton with large remodeling surfaces [40], but also occurs at cortical sites, and is associated with greater increases in biochemical markers of bone resorption than bone formation [41] (Figure 1). High-turnover bone loss after orchiectomy in men is prevented by bisphosphonates [41].

\section{Male Hypogonadism}

Men with hypogonadism have decreased serum testosterone levels due to many different causes. There is controversy regarding the lower end of the normal range for testosterone, but levels less than $150 \mathrm{ng} / \mathrm{dL}$ are typically associated with signs and symptoms of hypogonadism. Men with low testosterone levels due to primary gonadal failure, secondary pituitary dysfunction, or hypothalamic malfunction, have significantly lower bone density than age- and sex-matched controls, especially at trabecular skeletal sites such as the lumbar spine [42]. Several studies have reported high bone turnover associated with hypogonadism, but other studies show low bone turnover $[43,44]$. Testosterone replacement may increase bone formation on histomorphometric biopsy [44]. Some studies show that hypogonadism is associated with decreased calcium absorption and decreased serum 1,25-dihydroxyvitamin levels [45].

Hypogonadal men with low testosterone levels with or without decreased bone density have been reported to have increased fracture risk [46-49]. Hypogonadal men with low estradiol levels have also been reported to have increased fracture risk [50,51]. Men with spine or hip fracture have a higher prevalence of hypogonadism than expected [52], and men with hip fracture have increased bone resorption associated with hypogonadism [53]. Male hypogonadism is associated with a variety of disorders, each of which may have unique and independent effects on the skeleton. However, it appears that hypogonadism plays a more significant role in causation of bone loss than specific diseases [54]. Young men with delayed puberty have deceased DXA bone density at the lumbar spine, hip, and distal radius, as well as lower peak bone density [55]. However, volumetric bone density is normal in adult men with a history of delayed puberty, suggesting that the main effect of hypogonadism during skeletal growth is on bone size, rather than bone density [56].

Although estrogens are currently thought to play the dominant role in skeletal maturation and epiphyseal closure in both men and women, androgens play significant direct roles in skeletal development. It is not yet clear whether trabecular thickening or periosteal bone formation are directly affected by androgens, or primarily by estrogens aromatized from androgens [3]. Hypogonadism in men also results in estrogen deficiency of variable degrees, which may be partially compensated for by the ability to aromatize androgens [4]. However, hypogonadal men with very low androgen levels have only a limited ability to produce estrogens by aromatization.

\section{Androgen Resistance in Men}

Men with complete androgen insensitivity syndrome have decreased areal bone density at the lumbar spine and hip compared to age- and sex-matched controls [57], suggesting that androgens exert direct skeletal effects via the androgen receptor, and not just indirectly via aromatization to estrogens (Figure 2). However, surgical orchiectomy to prevent testicular 
tumors in this population, followed by hormone therapy, confounds bone density assessment in this population. Estrogen therapy typically increases bone density at the lumbar spine and hip in these men [58], although not all studies have adjusted bone density for the increased stature seen in these men. Androgen resistance is not associated with decreased longitudinal growth in men, but it is not known whether it is associated with decreased periosteal bone apposition.

\section{Skeletal Effects of Androgens in Women}

The role of androgens in maintenance of female skeletal health has not been clearly defined. Serum androgen levels vary considerably in women, with serum testosterone levels considerably lower than in men. However, levels of weaker adrenal androgens such as DHEA$\mathrm{S}$ and androstenedione are similar to those in men [59].

It is likely that androgens play a significant role in acquisition and maintenance of bone density in women, particularly at puberty. Women with polycystic ovary syndrome (PCOS), who develop variable hyperandrogenism at puberty [60], have increased peak bone density compared to age-matched controls as assessed by peripheral quantitative CT scanning, even after adjustment for increased body mass index [61]. Women with recognized PCOS commonly have an increased body mass index, changes in body composition, and menstrual irregularities that affect bone density independently of their hyperandrogenism. It is not yet clear whether androgens play a direct or indirect role in this situation. Obese PCOS patients have higher bone density than nonobese PCOS patients, possibly suggesting that aromatization of androgens in fat may play a significant role, or that increased biomechanical effects on the skeleton may be important. In addition, it is not yet clear whether low SHBG levels, which result in high bioavailable testosterone levels, or high insulin levels play a role in increasing bone density.

Androgen receptor blocker therapy, GnRH agonist therapy, or both for hirsutism, acne, or menstrual irregularities may worsen bone density in some women. In small uncontrolled studies, the androgen receptor blocker flutamide did not cause lumbar spine bone loss [62], whereas combination therapy with the androgen receptor blocker spironolactone and linestrenol caused lumbar spine bone loss [63]. GnRH agonist therapy causes bone loss in hirsute women unless they are simultaneously treated with gonadal hormone therapy [64]. However, combination therapy with a GnRH agonist and spironolactone, but not flutamide, caused bone density to remain stable in hirsute women treated for six months [65].

Androgen effects in postmenopausal women are less well documented. Menopause is associated with a 70\% decrease in adrenal androgens, including DHEA-S [59], but it is not yet clear that this decrease in weaker androgens contributes to bone loss or fractures. Several crosssectional studies have not shown an association between circulating DHEAS levels and bone density [66,67]. Adrenal androgens may have direct effects on bone via the androgen receptor, or indirect effects via aromatization.

\section{Skeletal Effects of Androgen Replacement}

The skeletal effects of androgen replacement have been most thoroughly studied in hypogonadal men. Testosterone increases skeletal calcium uptake in prepubertal boys [58]. Testosterone effects have also been investigated in small studies of men with delayed puberty, elderly men with partial hypogonadism, eugonadal men, and men with glucocorticoid-induced osteoporosis.

Testosterone therapy in long-term prospective and retrospective studies of male hypogonadism has been shown to increase bone density over about two years, particularly at trabecular skeletal 
sites [69]. After two years, bone density stabilizes, similar to what is seen during therapy with antiresorptive osteoporosis drugs. The increase in bone density in hypogonadal men is highly variable [54,70], and not seen in all studies [71], possibly due to differences in treatment duration, skeletal sites assessed, and study methodology. Quantitative CT (QCT) or peripheral QCT scanning typically demonstrate greater increases in trabecular bone density than DXA assessment [70,72], even though the QCT methods are not able to correct for androgen-induced reduction in marrow fat.

Most studies demonstrate that testosterone treatment decreases markers of bone resorption in hypogonadal men [70,72], and some studies also show decreases in markers of bone formation $[70,72]$. However, some studies show an initial increase in markers of bone formation in hypogonadal men treated with testosterone [71,73] or human chorionic gonadotropin [74]. Intramuscular or transdermal testosterone therapy in hypogonadal men increases lean body mass $[71,74]$ and muscle strength $[73,75]$ in some studies, but not others [76]. Since intramuscular testosterone injections may produce serum testosterone levels above the normal range, supra-physiological effects on bone potentially could occur in some patients [76]. Transdermal testosterone produces more physiological levels of serum testosterone [75], and is less likely to cause supra-physiological effects. However, retrospective studies have shown no apparent differences in bone density or adverse events in hypogonadal men treated with these forms of testosterone [76] (figure 3).

Most studies of testosterone replacement in hypogonadal men have been uncontrolled, relatively short-term, and involved small numbers of subjects with a variety of causes for their hypogonadism. Because most studies are uncontrolled, it is difficult to compare the bone density effects of testosterone replacement to those of calcium and/or vitamin D supplementation alone. Some studies show that testosterone replacement does not prevent bone loss in Klinefelter's syndrome patients [77]. A large retrospective study showed that hypogonadal men with the lowest bone density gain the most bone density during testosterone treatment [69]. Men with idiopathic hypogonadotropic hypogonadism who do not gain bone density during puberty may not be able to replace this later with testosterone replacement [78].

Because almost all studies of hypogonadal men have used aromatizable androgens for hormone replacement, it is difficult to determine whether the benefits seen are due to the testosterone administered or to the estradiol aromatized from testosterone. In one uncontrolled study of eugonadal men, testosterone therapy appeared to exert its beneficial effects mainly via increased serum estrogen levels, because serum estrogen levels increased more than testosterone levels [76]. There have been no reported studies of the skeletal effects of nonaromatizable dihydrotestosterone in hypogonadal men.

Skeletal effects of androgen replacement for indications other than hypogonadism are less well studied. Elderly men with partial androgen deficiency might potentially benefit from testosterone therapy for bone density, muscle strength, general mood, sexual function, and/or hematopoeiesis. However, the degree to which low levels of bioavailable testosterone contribute to bone loss in elderly men with partial hypogonadism is unclear, because several studies have failed to show strong or consistent associations between bioavailable testosterone and bone density $[67,79,80]$. Most studies have shown stronger correlations of estrogen with bone density in elderly men $[3,4]$. The randomized, double-blind, placebo-controlled trial by Snyder et al. [81] showed that transdermal testosterone therapy increased bone density over 36 months in elderly men with partial androgen deficiency, and that this increase was no greater than in the control group receiving calcium and vitamin D supplementation only. A significant portion of the men in this study were not truly hypogonadal, but had testosterone values in the lower part of the normal range. Interestingly, post-hoc analysis revealed a significant 
correlation between the baseline testosterone level and increases in BMD following testosterone therapy (Figure 4), suggesting that men with lower testosterone levels on entry were more likely to respond to testosterone replacement. In a similar study, Kenny et al. [82] showed that transdermal testosterone prevented bone loss, whereas calcium and vitamin D supplementation did not. Both studies showed that men with lower pre-treatment testosterone levels had greater improvement in bone density during testosterone treatment. Importantly, neither study gave convincing evidence for a threshold of serum testosterone necessary to protect bone density.

A single small 3-month study showed that treatment with nonaromatizable dihydrotestosterone did not decrease serum osteocalcin, a marker of bone turnover, in men with low-normal testosterone levels [83]. These findings imply that dihydrotestosterone does not have an effect on skeletal bone turnover and, as discussed later, may have implications for the skeletal impact of non-aromatizable androgens. Intramuscular testosterone therapy may be helpful in men with glucocorticoid-induced osteoporosis based on one study [84], but there are no long-term data on the effect of testosterone treatment on bone density or fractures in this population. A small study showed that low-dose testosterone supplementation in young men with delayed puberty caused increased bone density [85]. Combined androgen and estrogen therapy in postmenopausal women, with androgen given as low-dose testosterone or methyltestosterone, may have additional bone density benefit beyond the effect of estrogen alone [86], but sufficient safety and efficacy data are not currently available to recommend this form of combination therapy.

The weak androgen DHEA caused mild improvement in bone density and reduction in markers of bone resorption in a placebo-controlled, double-blind study in elderly women $>70$ years treated with DHEA $50 \mathrm{mg}$ daily [87]. A small uncontrolled study showed a similar modest benefit of DHEA in men [88]. Subjects in these studies had variable serum DHEA levels at baseline, and serum testosterone and estradiol levels both increased with treatment in both studies, suggesting that DHEA might act as a prohormone for gonadal sex steroids. A more recent prospective randomized, double-blind, placebo-controlled clinical trial of DHEA treatment in 87 elderly men and 57 elderly women with decreased DHEAS levels over two years [89] showed that DHEA $75 \mathrm{mg}$ daily in men and $50 \mathrm{mg}$ daily in women caused $<2 \%$ increases in femoral neck bone density in the men, and $<2 \%$ increases in ultradistal radius bone density in the women. Men in the trial who received transdermal testosterone $5 \mathrm{mg}$ daily had a comparable small increase in femoral neck bone density. Bone density did not change at other skeletal sites in either the men or women. These minimal findings suggest that DHEA does not play a major role in age-related bone loss in men or women.

\section{Skeletal Effects of Selective Modulation of Androgen Receptors in Men}

Relatively few studies have assessed the skeletal effects of androgen receptor antagonists, estrogen receptor antagonists, selective estrogen receptor modulators (SERMs), aromatase inhibitors, or type II $5 \alpha$-reductase inhibitors in men. Two small studies demonstrated that finasteride, a type II $5 \alpha$-reductase inhibitor, does not decrease lumbar spine bone density in men treated with finasteride for benign prostate hyperplasia [90,91]. These observations are likely due to the fact that osteoblasts predominantly express type I $5 \alpha$-reductase inhibitor [92]. The aromatase inhibitor anastrazole has been shown to increase bone resorption in older men [93]. Doran et al. [94] showed that the SERM raloxifene did not reduce markers of bone turnover in elderly men treated for six months, although further analysis revealed that the subset of men with low endogenous estradiol levels may have a beneficial skeletal response to raloxifene.

Falahati-Nini et al. [6] showed that estradiol is the dominant gonadal sex steroid regulating bone turnover in healthy elderly men by treating men with physiological testosterone and 
estradiol replacement for three weeks, and then withdrawing both testosterone and estradiol, testosterone alone, estradiol alone, or neither for an additional three weeks. Estradiol prevented increased markers of bone turnover more effectively than testosterone in these men, although both testosterone and estradiol were important in maintaining bone formation. A similar study by Leder et al. [7] in younger men over 12 weeks of treatment showed that testosterone and estradiol both independently regulate bone resorption and formation.

\section{Effects of Supra-physiological Doses of Androgens on Bone}

As noted earlier, there are currently no data on the use of supra-physiological doses of androgens on bone. Thus, the issue of whether high doses of androgens have different effects on bone metabolism than those defined for relatively physiological doses in the above studies remains unclear at present and requires future study. It is unclear, for example, whether beneficial direct or indirect (via aromatization to estrogen) effects of androgens on bone plateau at high androgen levels or not. However, one can speculate that these effects likely plateau since the replacement studies described above have found beneficial skeletal effects of androgens generally only in significantly hypogonadal men and marginal benefits, if any, in men with borderline testosterone levels. Moreover, given the increasing evidence that many of the effects of androgens on bone are due to aromatization to estrogens, it is possible that synthetic, non-aromatizable androgens may even have negative effects on bone metabolism due to suppression of endogenous testosterone (and estrogen) levels. This issue clearly requires further study and is a potential significant concern with steroid doping with non-aromatizable androgen compounds.

\section{Summary}

Androgens affect bone directly via interactions with androgen receptors, and indirectly via binding to ER $\alpha$ and $E R \beta$ after aromatization in fat or other tissues, or at the local tissue level, with effects dependent on the skeletal site, sex, age, degree of skeletal maturation, and species. Both androgens and estrogens preserve trabecular bone in males and females, regardless of age or species. Androgens and estrogens preserve trabecular bone primarily by decreasing osteoclastogenesis after interacting with bone marrow osteoblast precursors and possibly osteoclasts, and both prevent osteoblast apoptosis and stimulate osteoclast apoptosis. It has been difficult to assess the proportion of trabecular bone loss prevented by androgens and estrogens, but it appears that androgens exert their major effect on trabecular bone by local aromatization to estrogens. However, androgens have direct effects on trabecular bone mediated by androgen receptors in the absence of ER $\alpha$ or ER $\beta$, at least in rodents. It appears that most, if not all, effects of estrogens on trabecular bone are mediated by ER $\alpha$, although ER $\beta$ may modulate the action of ER $\alpha$. ER $\beta$ may mediate estrogen effects on longitudinal and radial bone growth.

Androgens stimulate cortical bone formation by increasing longitudinal bone growth at the epiphyseal growth plate and radial bone growth by periosteal apposition. Androgens and estrogens have similar biphasic effects on endochondral bone formation. Androgens stimulate bone formation and growth early in puberty, and epiphyseal closure later in puberty, with androgen effects on growth plate closure mediated by aromatization to estrogens and binding to ER $\alpha$. Low estrogen concentrations in men stimulate longitudinal bone growth, whereas higher estrogen levels inhibit longitudinal bone growth in women. It is likely that estrogen receptors mediate longitudinal bone growth, since there is not much evidence that androgen receptors mediate longitudinal bone growth in any species. Androgens stimulate radial bone growth by increasing periosteal apposition, whereas estrogens decrease such apposition. Most of the evidence for this comes from growing rodents, with post-pubertal effects less clear. In humans, androgens continue to stimulate periosteal bone growth later in life, thereby causing 
increased bone size relative to muscle mass in older age, and consequently increased bone strength. Given that trabecular and cortical volumetric bone density appear to be only mildly increased in younger women compared to younger men, and mildly decreased in older women compared to older men [95], larger bone size may explain the majority of the increased bone strength in men.

It is not clear whether androgen effects on cortical bone are mediated directly via cortical osteoblasts or indirectly via biomechanical strain due to increased body size and muscle mass. Both the androgen receptor and ER $\alpha$ appear to play a role in radial bone growth in males, with the androgen receptor playing the dominant role, based on data from rats with complete androgen resistance and androgen receptor knock-out mice. However, ER $\alpha$ stimulation causes increased periosteal bone formation in the absence of $E R \beta$, and treatment of rats with normal androgen levels and normal androgen receptors with aromatase inhibitors inhibits periosteal bone growth. It may be that radial bone growth is mediated predominantly by the androgen receptor, and to a lesser degree by ER $\alpha$, and inhibited by ER $\beta$ when stimulated by increased estrogen levels. This could explain why skeletal size stops increasing earlier in girls than boys, and why periosteal bone growth increases in postmenopausal women. The GH-IGF-1 system also plays a role in stimulating bone growth.

Treatment of marked hypogonadism in men with testosterone increases bone density and strength, but it is not yet clear that treatment of partial hypogonadism with androgen has the same effect. Selective androgen receptor modulators with stimulatory effects on bone and inhibitory effects on prostate would be beneficial for some men, and might also have application in certain metabolic bone diseases in some women. Tissue selective estrogen receptor modulators with preferential ER $\alpha$ activity in trabecular bone also might be beneficial in some men.

In summary, testosterone and other androgens exert major beneficial effects on bone cells and skeletal growth and homeostasis, with actions mediated by both the androgen receptor and estrogen receptors after aromatization of androgens. Both androgen and estrogen receptors play important roles during bone remodeling. ER $\alpha$ appears to play the dominant role in longitudinal growth of bone, whereas both the androgen receptor and ER $\alpha$ play a role in radial growth of bone. Whether supra-physiological doses of androgens have similar effects on bone as the physiological effects described here remains unresolved. In addition, whether high doses of synthetic, non-aromatizable androgens may, in fact, be detrimental to bone due to suppression of endogenous testosterone (and estrogen) levels is a potential concerns that warrants further study.

\section{References}

1. Vanderschueren D, Vandenput L, Boonen S, Lindberg MK, Bouillon R, Ohlsson C. Androgens and bone. Endocrine Rev 2004;25:389-425. [PubMed: 15180950]

2. Albright, F.; Reifenstein, EC. Metabolic bone disease: osteoporosis. In: Albright, F.; Reifenstein, EC., editors. The parathyroid glands and metabolic bone disease. Baltimore: Williams and Wilkins; 1948. p. 145-204.

3. Riggs BL, Khosla S, Melton LJ. Sex steroids and the construction and conservation of the adult skeleton. Endocrine Rev 2002;23:279-302. [PubMed: 12050121]

4. Khosla S, Melton LJ III, Riggs BL. Estrogen and the male skeleton. J Clin Endocrinol Metab 2002;87:1443-50. [PubMed: 11932262]

5. Juul A. The effects of estrogens on linear bone growth. Hum Reprod Update 2001;7:303-13. [PubMed: 11392377]

6. Falahati-Nini A, Riggs BL, Atkinson EJ, O'Fallon WM, Eastell R, Khosla S. Relative contributions of testosterone and estrogen in regulating bone resorption and formation in normal elderly men. J Clin Invest 2000;106:1553-60. [PubMed: 11120762] 
7. Leder BZ, LeBlanc KM, Schoenfeld DA, Eastell R, Finkelstein JS. Differential effects of androgens and estrogens on bone turnover in normal men. J Clin Endocrinol Metab 2003;88:204-10. [PubMed: 12519853]

8. Vanderscheueren D, Bouillon R. Androgens and bone. Calcif Tiss Int 1995;56:341-46.

9. Compston JE. Sex steroids and bone. Physiol Rev 2001;81:419-47. [PubMed: 11152762]

10. Carrascosa A, Audi L, Ferrandez MA, Balabriga A. Biological effects of androgens and identification of specific dihydrotestosterone-binding sites in cultured human fetal epiphyseal chondrocytes. J Clin Endocrinol Metab 1990;70:134-40. [PubMed: 2294127]

11. Abu EO, Horner A, Kusec V, Triffitt JT, Compston JE. The localization of androgen receptors in human bone. J Clin Endocrinol Metab 1997;82:3493-7. [PubMed: 9329391]

12. Ben-Hur H, Thole HH, Mashiah A, Insler V, Berman V, Shezen E, et al. Estrogen, progesterone and testosterone receptors in human fetal cartilaginous tissue: immunohistochemical studies. Calcif Tiss Int 1997;60:520-6.

13. van der Eerden BC, van Til NP, Brinkmann AO, Lowik CO, Wit JM, Karperien M. Gender differences in expression of androgen receptor in tibial growth plate and metaphyseal bone of the rat. Bone 2002;30:891-6. [PubMed: 12052459]

14. Bord S, Horner A, Beavan S, Compston J. Estrogen receptors $\alpha$ and $\beta$ are differentially expressed in developing human bone. J Clin Endocrinol Metab 2001;86:2309-14. [PubMed: 11344243]

15. Nilsson LO, Boman A, Savendahl L, Grigelioniene G, Ohlsson C, Ritzen EM, et al. Demonstration of estrogen receptor- $\beta$ immunoreactivity in human growth plate cartilage. J Clin Endocrinol Metab 1999;84:370-3. [PubMed: 9920110]

16. Colvard DS, Eriksen EF, Keeting PE, Wilson EM, Lubahn DB, French FS, et al. Identification of androgen receptors in normal human osteoblast-like cells. Proc Natl Acad Sci USA 1989;86:854-7. [PubMed: 2915981]

17. Wiren KM, Zhang X, Chang C, Keenan E, Orwoll ES. Transcriptional up-regulation of the human androgen receptor by androgen in bone cells. Endocrinology 1997;138:2291-2300. [PubMed: 9165014]

18. Bland R. steroid hormone receptor expression and action in bone. Clin Sci (Lond) 2000;98:217-40. [PubMed: 10657279]

19. Kasperk C, Helmboldt A, Borcsok I, Heuthe S, Cloos O, Niethard F, et al. Skeletal site-dependent expression of the androgen receptor in human osteoblastic cell populations. Calcif Tiss Int 1997;61:464-73.

20. Wiren K, Keenan E, Zhang X, Ramsay B, Orwoll E. Homologous androgen receptor up-regulation in osteoblastic cells may be associated with enhanced functional androgen responsiveness. Endocrinology 1999;140:3114-24. [PubMed: 10385404]

21. Pederson L, Kremer M, Judd J, Pascoe D, Spelsberg TM, Riggs BL, et al. Androgens regulate bone resorption activity of isolated osteoclasts in vitro. Proc Natl Acad Sci USA 1999;96:505-10. [PubMed: 9892663]

22. Mizuno Y, Hosoi T, Inoue S, Ikegami A, Kaneki M, Akedo Y, et al. Immuncytochemical identification of androgen receptor in mouse osteoclast-like cells. Calcif Tiss Int 1994;54:325-6.

23. Van der Eerden BC, Van De Ven J, Lowik CW, Wit JM, Karperien M. Sex steroid metabolism in the tibial growth plate of the rat. Endocrinology 2002;143:4048-55. [PubMed: 12239116]

24. Gruber R, Czerwenka K, Wolf F, Ho GM, Willheim M, Peterlik M. Expression of the vitamin D receptor, of estrogen and thyroid hormone receptor $\alpha$ - and $\beta$-isoforms, and of the androgen receptor in cultures of native mouse bone marrow and of stromal/osteoblastic cells. Bone 1999;24:465-73. [PubMed: 10321906]

25. Braidman IP, Hainey L, Batra G, Selby PL, Saunders PT, Hoyland JA. Localization of estrogen receptor $\beta$ protein expression in adult human bone. J Bone Miner Res 2001;16:214-20. [PubMed: 11204421]

26. Ren SG, Malozowski S, Sanchez P, Sweet DE, Loriaux DL, Cassorla F. Direct administration of testosterone increases rat tibial epiphyseal growth plate width. Acta Endocrinol (Copenh) 1989;121:401-5. [PubMed: 2800918]

27. Kerrigan JR, Rogol AD. The impact of gonadal steroid hormone action on growth hormone secretion during childhood and adolescence. Endocrine Rev 1992;13:281-98. [PubMed: 1618164] 
28. Kasperk CH, Wergedal JE, Farley JR, Linkhart TA, Turner RT, Baylink DJ. Androgens directly stimulate proliferation of bone cells in vitro. Endocrinology 1989;124:1576-8. [PubMed: 2521824]

29. Kasperk C, Fitzsimmons R, Strong D, Mohan S, Jennings J, Wergedal J, et al. Studies of the mechanism by which androgens enhance mitogenesis and differentiation in bone cells. J Clin Endocrinol Metab 1990;71:1322-9. [PubMed: 2229290]

30. Kasperk CH, Wakely GK, Hierl T, Ziegler R. Gonadal and adrenal androgens are potent regulators of human bone cell metabolism in vitro. J Bone Miner Res 1997;12:464-71. [PubMed: 9076590]

31. Hofbauer LC, Hicok KC, Khosla S. Effects of gonadal and adrenal androgens in a novel androgenresponsive human osteoblastic cell line. J Cell Biochem 1998;71:96-108. [PubMed: 9736458]

32. Bellido T, Jilka RL, Boyce BF, Girasole G, Broxmeyer H, Dalrymple SA, et al. Regulation of interleukin-6, osteoclastogenesis, and bone mass by androgens. J Clin Invest 1995;95:2886-95. [PubMed: 7769130]

33. Pilbeam CC, Raisz LG. Effects of androgens on parathyroid hormone and interleukin-1-stimulated prostaglandin production in cultured neonatal mouse calvariae. J Bone Miner Res 1990;5:1183-8. [PubMed: 2270781]

34. Fukuyama S, Tashjian AH Jr. Direct modulation by estradiol of the response of human bone cells (SaOS-2) to human parathyroid hormone (PTH) and PTH-related protein. Endocrinology 1989;124:397-401. [PubMed: 2909373]

35. Pivirotto LA, Cissel DS, Keeting PE. Sex hormones mediate interleukin-1 $\beta$ production by human osteoblastic HOBIT cells. Mol Cell Endocrinol 1995;111:67-74. [PubMed: 7649354]

36. Hofbauer LC, Hicok KC, Chen D, Khosla S. Regulation of osteoprotegerin production by androgens and anti-androgens in human osteoblastic lineage cells. Eur J Endocrinol 2002;147:269-73. [PubMed: 12153751]

37. Suda T, Takahashi N, Udagawa N, Jimi E, Gillespie MT, Martin TJ. Modulation of osteoclast differentiation and function by the new members of the tumor necrosis factor receptor and ligand families. Endocrine Rev 1999;20:345-57. [PubMed: 10368775]

38. Huber DM, Bendixon AC, Panthrose P, Srivastava S, Dienger KM, Shevde NK, et al. Androgens suppress osteoclast formation induced by RANKL and macrophage colony stimulating factor. Endocrinology 2001;142:3800-8. [PubMed: 11517156]

39. Smith MR. Osteoporosis during androgen deprivation therapy for prostate cancer. Urology 2002;60:79-85. [PubMed: 12231056]

40. Stoch SA, Parker RA, Chen L, Bubley G, Ko YJ, Vincelette A, et al. Bone loss in men with prostate cancer treated with gonadotropin-releasing hormone agonists. J Clin Endocrinol Metab 2001;86:2787-91. [PubMed: 11397888]

41. Smith MR, McGovern FJ, Zietman AL, Fallon MA, Hayden DL, Schoenfeld DA, et al. Pamidronate to prevent bone loss during androgen-deprivation therapy for prostate cancer. N Engl J Med 2001;345:948-55. [PubMed: 11575286]

42. Francis RM. The effects of testosterone on osteoporosis in men. Clin Endocrinol (Oxf) 1999;50:41114. [PubMed: 10468898]

43. Jackson JA, Kleerekoper M, Parfitt AM, Rao DS, Villanueva AR, Frame B. Bone histomorphometry in hypogonadal and eugonadal men with spinal osteoporosis. J Clin Endocrinol Metab 1987;65:538. [PubMed: 3584399]

44. Baran DT, Bergfeld MA, Teitelbaum SL, Avioli LV. Effect of testosterone therapy on bone formation in an osteoporotic hypogonadal male. Calcif Tiss Int 1978;26:103-6.

45. Francis RM, Peacock M, Aaron JE, Selby PL, Taylor GA, Thompson J, et al. Osteoporosis in hypogonadal men: role of decreased plasma 1,25-dihydroxyvitamin $\mathrm{D}$, calcium malabsorption, and low bone formation. Bone 1986;7:261-8. [PubMed: 3768204]

46. Baillie SP, Davison CE, Johnson FJ, Francis RM. Pathogenesis of vertebral crush fractures in men. Age Ageing 1992;21:139-41. [PubMed: 1575093]

47. Stanley HL, Schmitt BP, Poses RM, Deiss WP. Does hypogonadism contribute to the occurrence of a minimal trauma hip fracture in elderly men? J Am Geriatr Soc 1991;39:766-71. [PubMed: 2071807]

48. Mellstrom D, Johnell O, Ljunggren O, Eriksson AL, Lorentzon M, Mallmin H, et al. Free testosterone is an independent predictor of BMD and prevalent fractures in elderly men: MrOS Sweden. J Bone Miner Res 2006;21:529-35. [PubMed: 16598372] 
49. Meier C, Nguyen TV, Handelsman DJ, Schindler C, Kushnir MM, Rockwood AL, et al. Endogenous sex hormones and incident fracture risk in older men. Arch Intern Med 2008;168:47-54. [PubMed: 18195195]

50. Barrett-Connor E, Mueller JE, von Muhlen DG, Laughlin GA, Schneider DL, Sartoris DJ. Low levels of estradiol are associated with vertebral fractures in older men, but not women: the Rancho Bernardo Study. J Clin Endocrinol Metab 2000;85:219-23. [PubMed: 10634390]

51. Amin S, Zhang Y, Felsen DT, Sawin CT, Hannan MT, Wilson PWF, et al. Estradiol, testosterone, and the risk for hip fractures in elderly men from the Framingham Study. Am J Med 2006;119:42633. [PubMed: 16651055]

52. Seeman E, Melton LJ III, O’Fallon WM, Riggs BL. Risk factors for spinal osteoporosis in men. Am J Med 1983;75:977-83. [PubMed: 6650552]

53. Boonen S, Vanderscheueren D, Cheng XG, Verbeke G, Dequecker J, Geusens P, et al. Age-related (type II) femoral neck osteoporosis in men: biochemical evidence for both hypovitaminosis D- and androgen deficiency-induced bone resorption. J Bone Miner Res 1997;12:2119-26. [PubMed: 9421246]

54. Leifke E, Körner H-C, Link TM, Behre HM, Peters PE, Nieschlag E. Effects of testosterone replacement therapy on cortical and trabecular bone mineral density, vertebral body area and paraspinal muscle area in hypogonadal men. Eur J Endocrinol 1998;138:51-8. [PubMed: 9461316]

55. Finkelstein JS, Klibanski A, Neer RM. A longitudinal evaluation of bone mineral density in adult men with histories of delayed puberty. J Clin Endocrinol Metab 1996;81:1152-5. [PubMed: 8772591]

56. Bertelloni S, Baroncelli GI, Ferdeghini M, Perri G, Saggese G. Normal volumetric bone mineral density and bone turnover in young men with histories of constitutional delay of puberty. J Clin Endocrinol Metab 1998;83:4280-3. [PubMed: 9851764]

57. Bertelloni S, Baroncelli GI, Federico G, Cappa M, Lala R, Saggese G. Altered bone mineral density in patients with complete androgen insensitivity syndrome. Horm Res 1998;50:309-14. [PubMed: 9973670]

58. Mizunuma H, Soda M, Okano H, Kagami I, Miyamoto S, Ohsawa M, et al. Changes in bone mineral density after orchidectomy and hormone replacement therapy in individuals with androgen insensitivity syndrome. Hum Reprod 1998;13:2816-8. [PubMed: 9804237]

59. Labrie E, Belanger A, Cusan L, Gomez J-L, Candas B. Marked decline in serum concentration of adrenal C-19 sex steroid precursors and conjugated androgen metabolites during aging. Endocrinology 1997;82:2396-402.

60. Zborowski JV, Cauley JA, Talbott EO, Guzick DS, Winters SJ. Bone mineral density, androgens, and the polycystic ovary: the complex and controversial issue of androgenic influence. J Clin Endocrinol Metab 2000;85:3496-506. [PubMed: 11061489]

61. Buchanan JR, Hospodar P, Myers C, Leuenberger P, Demers LM. Effect of excess endogenous androgens on bone density in young women. J Clin Endocrinol Metab 1988;67:937-43. [PubMed: 2972738]

62. Bertelloni S, Baroncelli GI, Sorrentino MC, Costa S, Sattini R, Saggese G. Androgen-receptor blockade does not impair bone mineral density in adolescent females. Calcif Tiss Int 1997;61:1-5.

63. Prezelj J, Kocijancic A. Antiandrogen treatment with spironolactone and linestrenol decreases bone mineral density in eumenorrheic women with androgen excess. Horm Metab Res 1994;26:46-8. [PubMed: 8150424]

64. Simberg N, Tiltinen A, Silfvast A, Viinikka L, Ylikorkala O. High bone density in hyperandrogenic women: effect of gonadotropin-releasing hormone agonist alone or in conjunction with estrogenprogestin replacement. J Clin Endocrinol Metab 1996;81:646-651. [PubMed: 8636283]

65. Moghetti P, Castello R, Zamberlan N, Rossini M, Gatti D, Negri C, et al. Spironolactone, but not flutamide, administration prevents bone loss in hyperandrogenic women treated with gonadotropinreleasing hormone agonist. J Clin Endocrinol Metab 1999;84:1250-4. [PubMed: 10199763]

66. Barrett-Connor E, Kritz-Silverstein D, Edelstein SL. A prospective study of dehydroepiandrosterone sulfate (DHEAS) and bone mineral density in older men and women. Am J Epidemiol 1993;137:2016. [PubMed: 8452124] 
67. Greendale GA, Edelstein S, Barrett-Connor E. Endogenous sex steroids and bone mineral density in older women and men: the Rancho Bernardo study. J Bone Miner Res 1997;12:1833-43. [PubMed: 9383688]

68. Mauras N, Haymond MW, Darmaun D, Vieira NE, Abrams SA, Yergey AL. Calcium and protein kinetics in prepubertal boys. Positive effects of testosterone. J Clin Invest 1994;93:1014-9. [PubMed: 8132741]

69. Behre HM, Kliesch S, Liefke E, Link TM, Nieschlag E. Long-term effect of testosterone therapy on bone mineral density in hypogonadal men. J Clin Endocrinol Metab 1997;82:2386-90. [PubMed: 9253305]

70. Katznelson L, Finkelstein JS, Schoenfeld DA, Rosenthal DI, Anderson EJ, Klibanski A. Increase in bone density and lean body mass during testosterone administration in men with acquired hypogonadism. J Clin Endocrinol Metab 1996;81:4358-65. [PubMed: 8954042]

71. Wang C, Eyre DR, Clark K, Kleinberg D, Newman C, Iranmanesh A, et al. Sublingual testosterone replacement improves muscle mass and strength, decreases bone resorption, and increases bone formation markers in hypogonadal men - a clinical research center study. J Clin Endocrinol Metab 1996;81:3654-62. [PubMed: 8855818]

72. Snyder PJ, Peachey H, Berlin JA, Hannoush P, Haddad G, Diewati A, et al. Effects of testosterone replacement in hypogonadal men. J Clin Endocrinol Metab 2000;85:2670-7. [PubMed: 10946864]

73. Wang C, Swerdloff RS, Iranmanesh A, Dobs A, Synder PJ, Cunningham G, et al. Effects of transdermal testosterone gel on bone turnover markers and bone mineral density in hypogonadal men. Clin Endocrinol (Oxf) 2001;54:739-50. [PubMed: 11422108]

74. Guo C-Y, Jones TH, Eastell R. Treatment of isolated hypogonadotropic hypogonadism effect on bone mineral density and bone turnover. J Clin Endocrinol Metab 1997;82:658-65. [PubMed: 9024272]

75. Wang C, Swerdloff RS, Iranmanesh A, Dobs A, Snyder PJ, Cunningham G, et al. Transdermal testosterone gel improves sexual function, mood, muscle strength, and body composition parameters in hypogonadal men. Testosterone Gel Study Group. J Clin Endocrinol Metab 2000;85:2839-53. [PubMed: 10946892]

76. Anderson FH, Francis RM, Faulkner K. Androgen supplementation in eugonadal men with osteoporosis - effects of 6 months of treatment on bone mineral density and cardiovascular risk factors. Bone 1996;18:171-7. [PubMed: 8833211]

77. van den Bergh JP, Hermus AR, Spruyt AI, Sweep CG, Corstens FH, Smals AG. Bone mineral density and quantitative ultrasound parameters in patients with Klinefelter's syndrome after long-term testosterone substitution. Osteoporosis Int 2001;12:55-62.

78. Finkelstein JS, Klibanski A, Neer RM, Doppelt SH, Rosenthal KI, Crowley WF. Increases in bone density during treatment of men with idiopathic hypogonadotropic hypogonadism. J Clin Endocrinol Metab 1989;69:776-83. [PubMed: 2674186]

79. Khosla S, Melton LJ 3rd, Atkinson EJ, O’Fallon WM, Klee GG, Riggs BL. Relationship of serum sex steroid levels and bone turnover markers with bone mineral density in men and women: a key role for bioavailable estrogen. J Clin Endocrinol Metab 1998;83:2266-74. [PubMed: 9661593]

80. Kenny AM, Prestwood KM, Marcello KM, Raisz LG. Determinants of bone density in healthy older men with low testosterone levels. J Gerontol A Biol Sci Med Sci 55A:M492-M497.

81. Snyder PJ, Peachey H, Hannoush P, Berlin JA, Loh L, Holmes JH, et al. Effect of testosterone treatment on bone mineral density in men over 65 years of age. J Clin Endocrinol Metab 1999;84:1966-72. [PubMed: 10372695]

82. Kenny AM, Prestwood KM, Gruman CA, Marcello KM, Raisz LG. Effects of transdermal testosterone on bone and muscle in older men with low bioavailable testosterone levels. J Gerontol A Biol Sci Med Sci 56:M266-M272. [PubMed: 11320105]

83. Ly LP, Jimenez M, Zhuang TN, Celermajer DS, Conway AJ, Handelsman DJ. A double-blind, placebo-controlled, randomized clinical trial of transdermal dihydrotestosterone gel on muscular strength, mobility, and quality of life in older men with partial androgen deficiency. J Clin Endocrinol Metab 2001;86:4078-88. [PubMed: 11549629]

84. Reid IR, Wattie DJ, Evans MC, Stapleton JP. Testosterone therapy in glucocorticoid-treated men. Arch Intern Med 1996;156:1173-7. [PubMed: 8639011] 
85. Bertelloni S, Baroncelli GI, Battini R, Perri G, Saggese G. Short-term effects of testosterone treatment on reduced bone density in boys with constitutional delay of puberty. $\mathrm{J}$ Bone Miner Res 1995;10:1488-95. [PubMed: 8686504]

86. Raisz LG, Wiita B, Artis A, Bowen A, Schwartz S, Trahiotis M, et al. Comparison of the effects of estrogen alone and estrogen plus androgen on biochemical markers of bone formation and resorption in postmenopausal women. J Clin Endocrinol 1996;81:37-43.

87. Baulieu E-E, Thomas G, Legrain S, Lahlou N, Roger M, Debuire B, et al. Dehydroepiandrosterone (DHEA), DHEA sulfate, and aging: contribution of the DHEAge study to a sociobiomedical issue. Proc Natl Acad Sci USA 2000;94:4279-84. [PubMed: 10760294]

88. Villareal DT, Holloszy JO, Kohrt WM. Effects of DHEA replacement on bone mineral density and body composition in elderly women and men. Clin Endocrinol (Oxf) 2000;53:561-8. [PubMed: 11106916]

89. Nair KS, Rizza RA, O’Brien P, Dhatariya K, Short KR, Nehra A, et al. DHEA in elderly women and DHEA or testosterone in elderly men. N Engl J Med 2006;355:1647-59. [PubMed: 17050889]

90. Matzkin H, Chen J, Weisman Y, Goldray D, Pappas F, Jaccard N, et al. Prolonged treatment with finasteride (a $5 \alpha$-reductase inhibitor) does not affect bone density and metabolism. Clin Endocrinol (Oxf) 1992;37:432-6. [PubMed: 1283117]

91. Tollin SR, Rosen HN, Zurowski K, Saltzman B, Zeind AJ, Berg S, et al. Finasteride therapy does not alter bone turnover in men with benign prostate hyperplasia - a clinical research center study. J Clin Endocrinol Metab 1996;81:1031-4. [PubMed: 8772571]

92. Issa S, Schnabel D, Feix M, Wolf L, Schaefer HE, Russell DW, et al. Human osteoblast-like cells express predominantly steroid 5 $\alpha$-reductase type 1. J Clin Endocrinol Metab 2002;87:5401-7. [PubMed: 12466325]

93. Taxel P, Kennedy DG, Fall PM, Willard AK, Clive JM, Raisz LG. The effect of aromatase inhibition on sex steroids, gonadotropins, and markers of bone turnover in older men. J Clin Endocrinol Metab 86:2869-74. [PubMed: 11397902]

94. Doran PM, Riggs BL, Atkinson EJ, Khosla S. Effects of raloxifene, a selective estrogen receptor modulator, on bone turnover markers and serum sex steroid and lipid levels in elderly men. $\mathrm{J}$ Bone Miner Res 2001;16:2118-25. [PubMed: 11697809]

95. Riggs BL, Melton LJ III, Robb RA, Camp JJ, Atkinson EJ, Peterson JM, et al. Population-based study of age and sex differences in bone volumetric density, size, geometry, and structure at different skeletal sites. J Bone Miner Res 2004;19:1945-54. [PubMed: 15537436] 

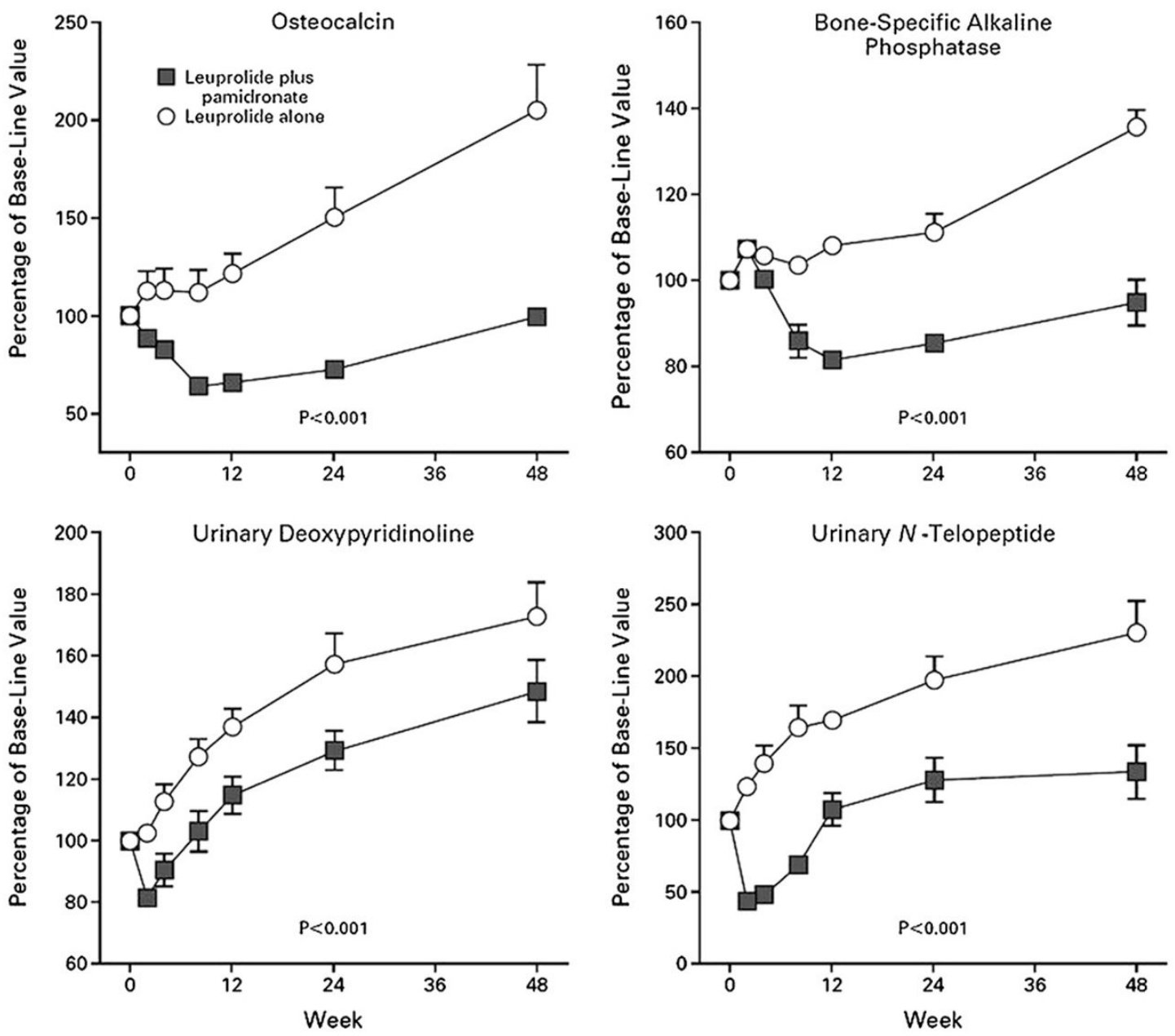

Figure 1.

Changes in serum concentrations of Bone Specific Alkaline Phosphatase and Osteocalcin and urinary excretion of Deoxypyridinoline and N-Telopeptide in men with prostate cancer treated with Leuprolide alone or Leuprolide and Pamidronate. Values are expressed as the mean $( \pm$ $\mathrm{SE}$ ) percentage of the baseline value. $\mathrm{P}$ values are for the treatment effect according to the repeated-measures analysis of covariance controlled for the baseline value. Standard error bars that are not visible are covered by the symbol. 


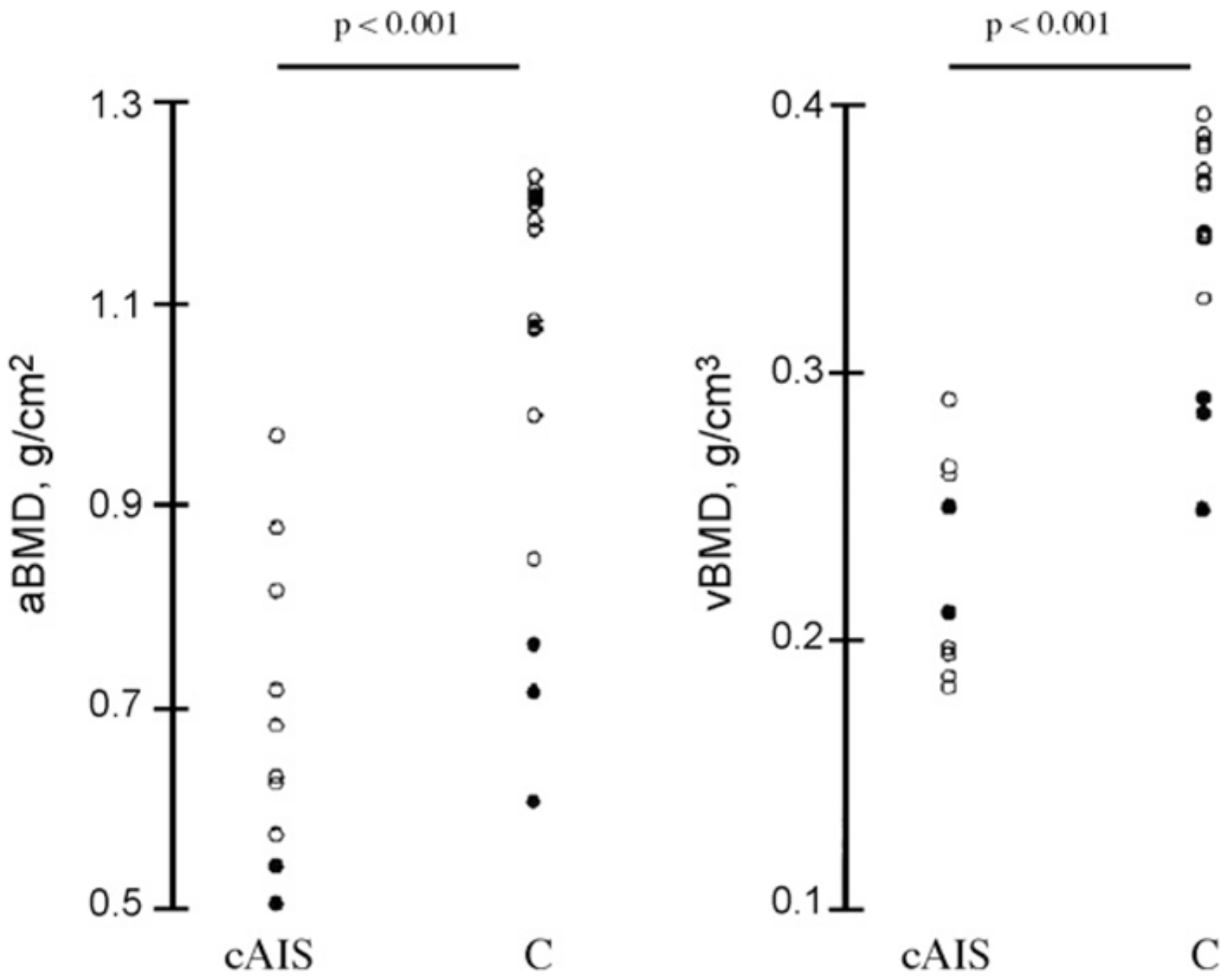

Figure 2.

Measured areal and volumetric BMD in patients with complete androgen insensitivity syndrome (cAIS) and in controls (C). In each group, dark circles are prepubertal patients, and open circles are pubertal patients. 


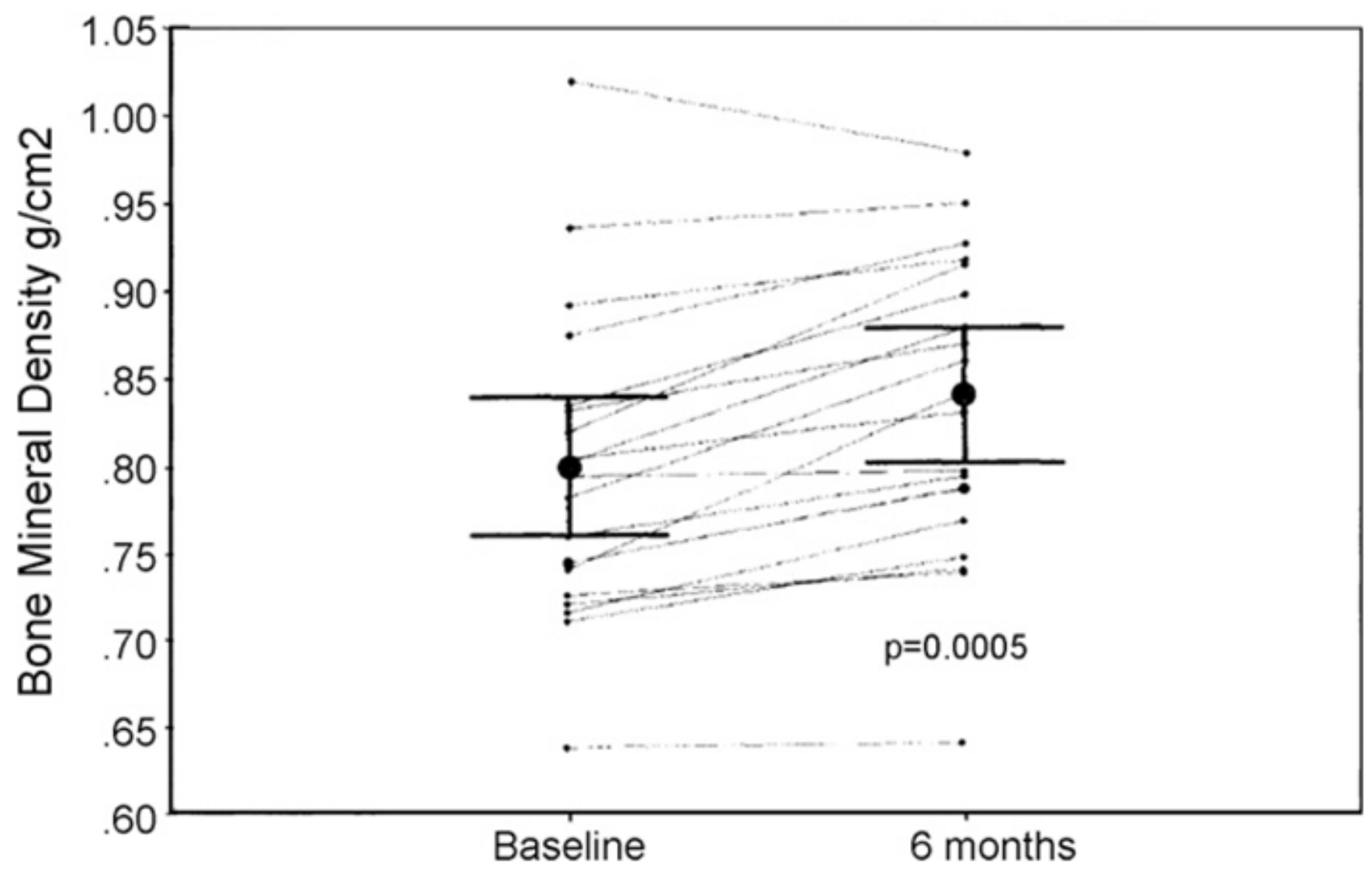

Figure 3.

Changes in lumbar spine BMD measurement in individual patients during treatment with testosterone. Error bars show mean $\pm 95 \%$ confidence intervals. 

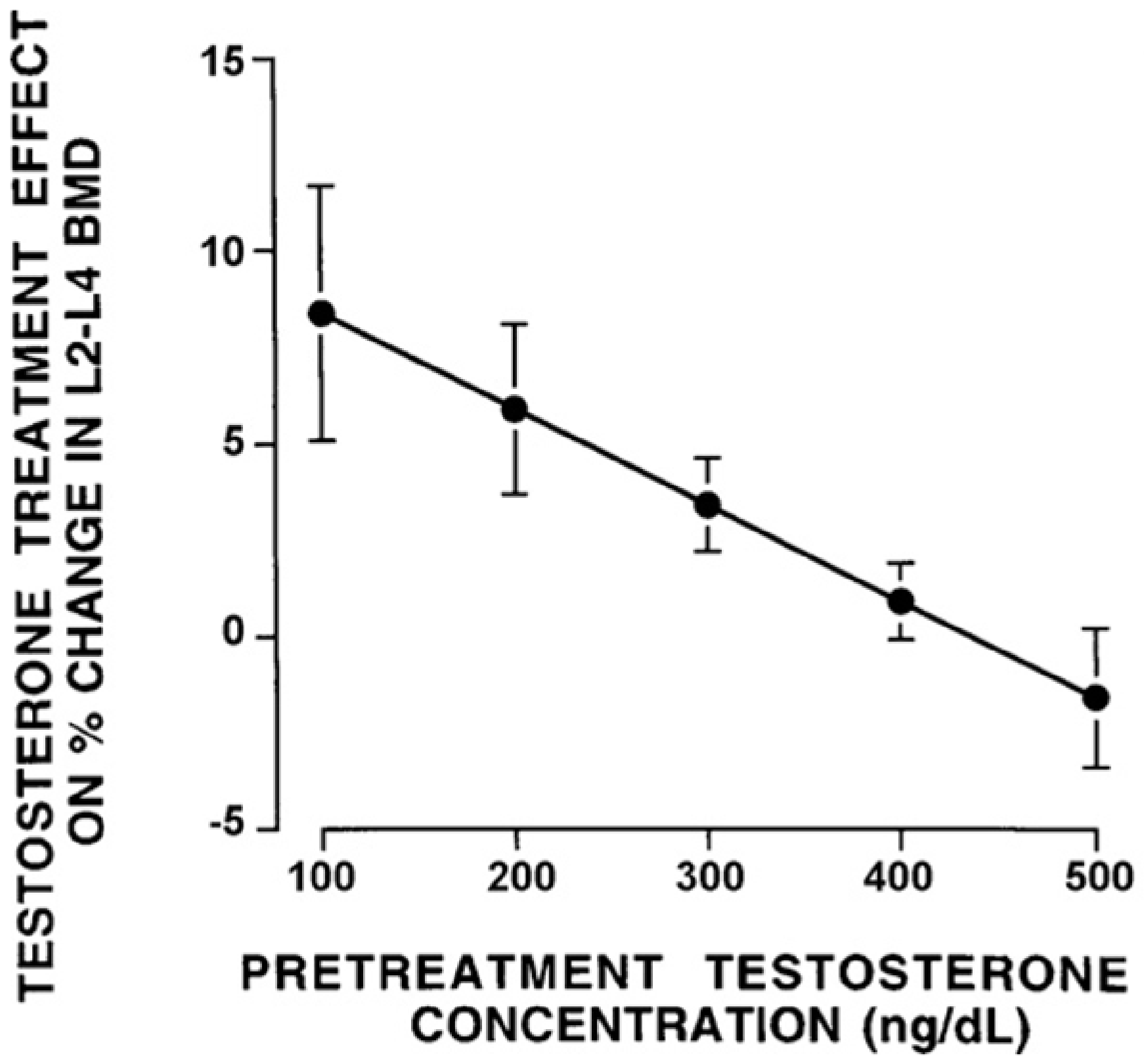

Figure 4.

The testosterone treatment effect on BMD change during 36 months of testosterone treatment in men over 65 years of age as a function of the pretreatment serum testosterone concentration. The lower the pretreatment serum testosterone concentration, the greater the effect of testosterone treatment on BMD. This relationship was derived from linear regression analysis of the pretreatment serum testosterone concentrations and the increments in BMD of all 108 men in the study who were treated with testosterone or placebo. The values shown are the mean $( \pm$ SE) changes in BMD during the 36 months of treatment in the testosterone-treated subjects minus those in the placebo-treated subjects for pretreatment testosterone concentrations from $100-500 \mathrm{ng} / \mathrm{dL}$. The testosterone treatment effect was statistically significant $(\mathrm{P}<0.01)$ for pretreatment serum testosterone concentrations of 100-300 ng/dL. 